Available online at: https://journals.researchsynergypress.com/index.php/ijrse

International Journal of Research in STEM Education (IJRSE)

ISSN 2721-2904 (Online) | 2721-3242 (Print)

Volume 3 Number 1 (2021): 01-06

\title{
Students' Perception of Online Learning During Covid-19: An Evidence from University of Muhammadiyah Banda Aceh, Indonesia
}

\author{
Siti Safura ${ }^{1}$ \\ 1Muhammadiyah Banda Aceh University, Indonesia
}

\begin{abstract}
The pandemic of Coronavirus has influenced all levels of education in the whole world. This impact forces the Ministry of Education to switch from traditional education to online education. As a result, educators must run this policy to teach the classroom and students must adapt to this situation. This research aimed to find out students' perception of online learning during the Coronavirus pandemic. This research employed the descriptive quantitative research method and gathered data by distributing the questionnaires. The object of this research was twenty-seven students with the number of populations was thirty-one students from different semester of the English Department, University of Muhammadiyah Aceh. The obtained data was analyzed through descriptive analysis to see how online class is perceived by students during pandemic. The result of this research shows that the students shared the positive perceptions towards online learning during the Coronavirus pandemic. The finding also displays the hesitation of students about the difficulty faced in having the online class.
\end{abstract}

Keywords: Coronavirus, Pandemic, Students Perception, Online Learning

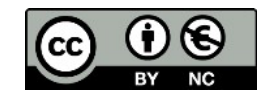

This is an open access article under the CC-BY-NC license

\section{INTRODUCTION}

When Ministry of Education makes a policy to learn from home or take the classroom at home through online learning (Hidayat, 2020) during COVID-19 Pandemic period, this model of learning is considered as the current model in the educational system. This model of education has become a widespread practice over the years as an integrated technology in education(Agung \& Surtikanti, 2020). Online learning is the process of education that takes place over the internet. It is often referred to as elearning (Kessler, 2018). E-learning has grown in significance as media to develop educational quality. The use of this model in the teaching-learning process causes many changes in educational activities.

During covid 19, this model of learning becomes a highlight at all levels of education. This situation forces teachers and students to use technology as media to have an online class. This technology is naturally helpful for educators in having a classroom. It facilitates all educational activities by the end of the decade. Rey (2016) stated that online learning is a way to structure the instruction in which supports content organization optimally and student interaction. Moreover, Mamattah (2016), Bali \& Liu, (2018) revealed online learning is an innovative idea and creative learning technology that motivate students to the chance and improve learning by using a variety of technology. On the other hand, the use of online learning also has a limitation in which it will have a challenges itself, such as internet connectivity (Priyanka Gautam, 2020), troubleshooting of technology (Bagata, 2020), and misunderstanding of communication(Mohammad Alawamleh, Lana Mohannad Al-twait, 2020).

It is no doubt that the presence of covid 19 has a significant impact on the system of education that could give benefits, however, it also takes a challenge for the educational world. It is due to students face a new form of learning that requires adaption with the online system. Thus, the researcher aims to 
conduct a study regarding students' perception of using online class during pandemic at English Department, University of Muhammadiyah Aceh.

\section{LITERATURE REVIEW}

There are some advantages of online learning that give benefit in learning activities during the pandemic. Firstly, online learning gives educators and students flexibility and accessibility to complete their classroom, in which, they can attend the class or work from home without necessarily having class in institutions or campus (Mcdonald, 1999). Regarding to this, this online education is considered could increase students' interest and motivation, due to students are free to choose their time and place for their learning and conduct all learning activities at home.

Secondly, the benefit of online education is more affordable as compared to face-to-face learning. This reduces financial costs such as transportation, students' meals, and paperless learning (Priyanka Gautam, 2020). Also, Cavanaugh et al., (2009) stated that "Online programs have little or no cost to educational facilities, transportation, and associated staff." So, it is good news for students, educators, and institutions to eliminate the budget cost in this pandemic.

Last, this online education changes the educational system during the pandemic. Educators change their learning styles to provide the teaching-learning process. They develop the content of the material to ease in understanding. The effectiveness of online learning depends on how the content is designed to overcome and understand the obstacles faced by students (Muthuprasad et al., 2021). As well, Ferreira et al., (2018) stated that an educator must be able to explore and use all technologies related to the learning process. It definitely improves the teachers or lecturers of using technology as supposed the technology application increase over time.

Aside from the advantages of e-learning during the pandemic, it also has limitations. It is about readiness. The rapid growth of technology makes students, educators, parents, and institutions not ready to utilize technology in learning activities. It forces all levels of students, educators, parents, and institutions to use e-learning applications to learn or work at home during this pandemic (Hidayat, 2020). Consequently, it makes the teaching-learning process unsuccessful.

Apart from readiness, the technological issues regarding internet connectivity become a big challenge for all levels of people to complete their learning activities. The Internet has grown in leaps and bounds over the past few years, in smaller cities and towns, but a consistent connection with decent speed is a problem (Priyanka Gautam, 2020). Additionally, the issue of using the internet, in which it takes cost to purchase the internet, becomes the concern issues in this time of the pandemic. This is absolutely unfavorable to the education process.

Last, online education is considered not effective in the way of transferring knowledge and providing information. The way how educators communicate and interact with the students can be an obstacle during an online class. The online interaction is one of the triggers of understanding the content of the material. As indicated from the journal of Mohammad Alawamleh, Lana Mohannad Al-twait (2020), some students perceived the medium as "faceless," and there could be misunderstandings. Concerning this, students become unsatisfied and less motivated to learn with this model of learning.

Pertaining to the explanation above, online learning is highlighted as an effective and successful way to have teaching learning process during Coronavirus. This study solely focuses on students' views toward the use of online class in terms of positive and negative aspects. 


\section{RESEARCH METHOD}

This research is quantitative research method. This research was conducted at the English Department, University of Muhammadiyah Aceh. The questionnaires are employed as instruments to collect data for this research. This questionnaire was adapted and modified from (Sari et al., 2020) and (Bagata, 2020) which questions about students' perception in the use of online learning during pandemic.

Then, the questionnaire was distributed online by using Google form to 27 students from different semesters with the number of populations was 31 students. The instrument was developed with a total of 22 questions using a Likert scale with four alternative answers, namely: 1 (strongly disagree), 2 (disagree), 3 (agree), and 4 (strongly agree). The Likert scale was used to measure attitudes, opinions, and perceptions of events or social phenomena (Riduwan, 2007). To ease students in understanding questions, the questionnaire was divided into positive statement and negative statement, each consist of 11 questions regarding the benefit and difficulty of online learning.

To analyze the data, descriptive analysis was applied to know students' perception of online class during pandemic Covid 19. Descriptive analysis is a way to review or explain the collected data as it is (Purwanto, 2007).

\section{FINDINGS AND DISCUSSION}

The result of questionnaires regarding students' perception of online learning during the Coronavirus pandemic shows that the different perceptions of participants in filling out the questionnaire items. The participants tend perceiving that online learning has benefits during the pandemic, compared to the problem faced. To ease in analyzing and understanding the result of data, the researcher provides the description of data at once. Indeed, the results of questionnaires are described as follows:

\section{These statements contain the benefits/advantages of online learning \\ 27 responses}

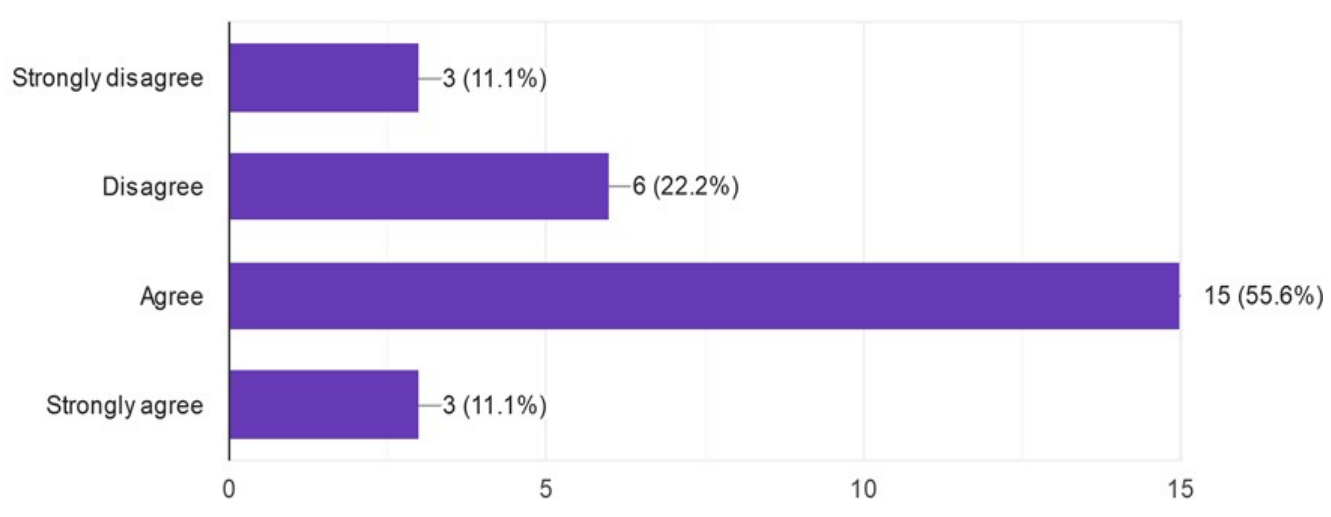

Figure 1. Student's perception of benefits of online learning

From figure 1, it can be seen that there are 3 participants (11.1\%) who choose strongly agree, 15 participants (55,6\%) prefer to agree, 6 participants (22.2\%) choose disagree, and 3 participants $(11.1 \%)$ 
decide strongly disagree. This figure indicates that the using of online learning during pandemic gives good impact for students. In other words, students could enjoy class and understand the material given by lecturer through online system.

\section{These statements are about the difficulty faced/disadvantages of online learning \\ 27 responses}

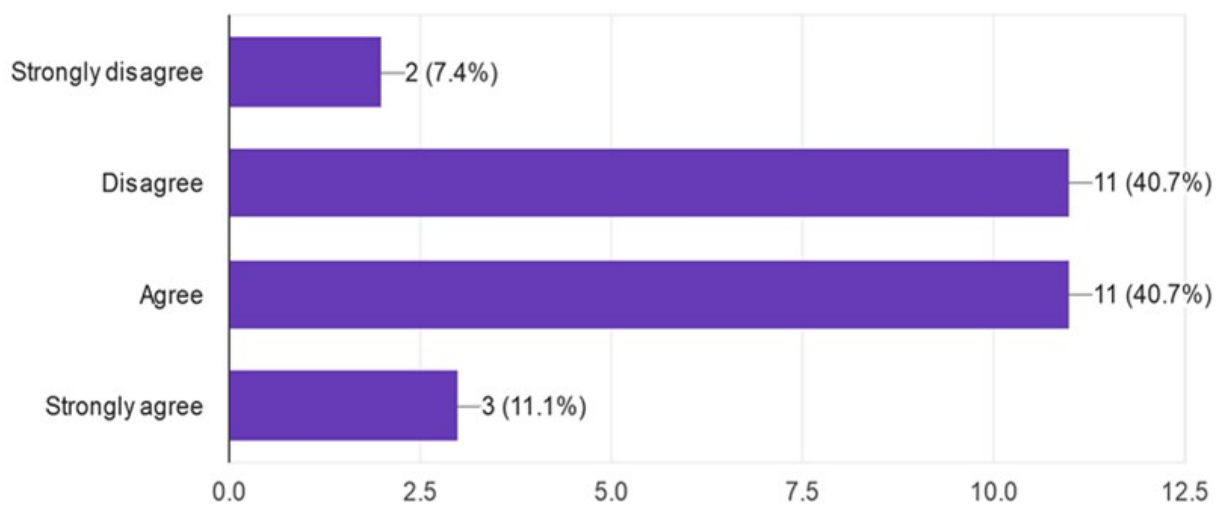

Figure 2. Students' perception of challenges of online learning

From figure 2, it can be seen that there are 3 participants (11.1\%) who choose strongly agree, 11 participants (40.7\%) who prefer agree as well as disagree, and 2 participants (7.4\%) who vote strongly disagree. This figure displays the similar voting between "agree" and "disagree" that could indicated the uncertainty of participants in perceiving the online learning during pandemic. This may happen because some students are familiar with online class, but some others get difficulty with learning online system.

To see the significant comparison between benefits and challenges of online learning are displayed as follows:

These statements contain the benefitsladvantages of online learning

27 responses
These statements are about the difficulty facedldisadvantages of online learning

27 responses

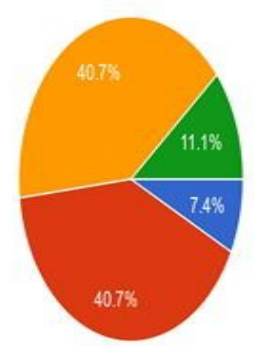

Stronglydisagree

Disagree

O Agree

Strongly agree

Figure 3. The comparison of students' perception 
Online learning during covid-19 pandemic is illustrating how important education in life. The presence of coronavirus forces education system or institutions to stay readiness in implementing learning. This research is aimed to know how the students perceive online learning during coronavirus, whether it has benefits or difficulties. This research found that the majority of students (55.6\%) perceive that online learning assist them in this situation. Students can improve their learning, encourage their motivation, and understand the material through online classroom. This study is supported by a result of a study by Yulia (2020) that found the use of online class during pandemic is the effective way to keep learning. Similarly, the study conducted by Hidayat (2020) which found that online learning is an interesting and fun media in learning.

Meanwhile, this research found the unpredicted finding regarding the difficulties faced by students during online learning in terms of the similar result between agree and disagree which is $40,7 \%$. In voting this statement, students felt not sure about the difficulty of using online learning. This finding can be assumed that online learning is not a significant obstacle for them. This finding is in line with a study conducted by Bagata (2020) which found that online learning was not a challenged to learn during this situation (Pandemic).

Therefore, from the explanation of finding above, the students' perception of online learning as online education tends to create the positive impact compared to the negative impact.

\section{CONCLUSION}

During the Coronavirus pandemic, the online learning model is applying at all levels of education. The high speed of this virus forces the system of education to transform a face-to-face class to the online class. This research is conducted to see students' perception of online learning during the Covid 19 pandemic. This current research concludes that online learning has a good contribution for students during this pandemic. Even though online class perceived could give the positive effect for helping students in studies and encourages their learning, online class actually has the challenges for students. For further researches, it suggested to see specifically the challenges of online classes and explore how to overcome the difficulty of online education becomes a trend in the education system.

\section{REFERENCES}

Agung, A. S. N., \& Surtikanti, M. W. (2020). Students' Perception of Online Learning during COVID19 Pandemic: A Case Study on the English Students of STKIP Pamane Talino. SOSHUM: Jurnal Sosial Dan Humaniora, 10(2), 225-235. https://doi.org/10.31940/soshum.v10i2.1316

Bagata, D. T. R. (2020). EFL University Students' Perception of the Use of Online Learning Platform in the Covid 19 Pandemic. Jurnal Penelitian, Pendidikan, Dan Pembelajaran UNISMA, 15(34). http://riset.unisma.ac.id/index.php/jp3/article/view/8102

Bali, S., \& Liu, M. C. (2018). Students' perceptions toward online learning and face-to-face learning courses. Journal of Physics: Conference Series, 1108(1). https://doi.org/10.1088/17426596/1108/1/012094

Cavanaugh, C. S., Barbour, M. K., \& Clark, T. (2009). Research and practice in K-12 online learning: A review of open access literature. International Review of Research in Open and Distance Learning, 10(1). https://doi.org/10.19173/irrodl.v10i1.607

Ferreira, J., Behrens, M., Torres, P., \& Marriott, R. (2018). The necessary knowledge for online education: Teaching and learning to produce knowledge. Eurasia Journal of Mathematics, 
International Journal of Research in STEM Education(IJRSE), Vol. 3 (1),01-06

Students Perception of Online Learning During Covid-19: An Evidence of Muhammadiyah Banda Aceh University, Indonesia

SitiSafura

\begin{tabular}{llccc}
\hline $\begin{array}{l}\text { Science } \\
\text { https://doi.org/10.29333/ejmste/86463 }\end{array}$ & Education, & 14(6), & 2097-2106.
\end{tabular}

Hidayat, A. (2020). Student s ' Perceptions of E-learning During Covid-19 Pandemic. 2(2), 34-45. Kessler, G. (2018). Introduction to Teaching and Technology. The TESOL Encyclopedia of English Language Teaching, 1-2. https://doi.org/10.1002/9781118784235.eeltv06b

Mamattah, R. S. (2016). Students 'Perceptions of E-Learning. Lingkoping University.

Mcdonald, D. S. (1999). Improved Training Methods Through the Use of Multimedia Technology. Journal of Computer Information Systems, 40(2), 14-22.

Mohammad Alawamleh, Lana Mohannad Al-twait, G. R. A. (2020). The Effect of Online Learning on Communication Instructors and Students During Covid-19. Asian Education and Development Studies, 9(4), 1-12.

Muthuprasad, T., Aiswarya, S., Aditya, K. S., \& Jha, G. K. (2021). Students' perception and preference for online education in India during COVID -19 pandemic. Social Sciences \& Humanities Open, 3(1), 100101. https://doi.org/10.1016/j.ssaho.2020.100101

Priyanka Gautam. (2020). Advantages and Disadvantages of Online Learning. In Elearning Industry. https://elearningindustry.com/advantages-and-disadvantages-online-learning

Purwanto. (2007). Inferential Statistic Lab Guide.

Rey, P. G. (2016). Measuring Teachers And Learners' Perceptions Of The Quality Of Their Online Learning ExperienceNo Title. Distance Education, 37(2), 146-163.

Riduwan, H. S. (2007). Introduction to Statistics for Research: Educational, Social, Economic and Business. Alfabeta.

Sari, W. P., Pramesti, D., \& Kusuma, A. I. (2020). Student's perception of online learning in pandemic. Proceding "International Webinar on Education 2020," 201-207.

Yulia, H. (2020). Online Learning to Prevent the Spread of Pandemic Corona Virus in Indonesia. ETERNAL (English Teaching Journal), 11(1), 48-56. https://doi.org/10.26877/eternal.v11i1.6068 